\title{
Pengaruh Masa Pandemi Covid 19 Terhadap Wirausaha Kecil Di Indonesia
}

\author{
${ }^{1}$ Nogi Sugianti \\ ${ }^{1}$ Ekonomi Syariah, Fakultas Ekonomi dan Bisnis islam, Universitas Islam Negeri \\ Sultan Thaha Saifuddin Jambi
}

Article history

Received:04-Mei- 2021

Revised: 12-Juni-2021

Accepted:108-July-2021

*Corresponding Author:

Nogi Sugianti,

Ekonomi Syariah,

Fakultas Ekonomi dan

Bisnis islam,

Universitas Islam Negeri

Sultan Thaha Saifuddin

Jambi

Email:

Nogisugianti11@gmail.co

$\mathrm{m}$

\section{PENDAHULUAN}

Awal kemunculan pandemi covid-19 berasal dari Wuhan, China yang meyebar hingga seluruh dunia termasuk di Indoneisa tepatnya awal maret 2020. Penyebaran virus ini dapat melalui kontak fisik manusia melalui hidung, mulit dan mata. Dampak yang ditimbulkan dari wabah ini dirasakan oleh hampir seluruh sektor. Pemerintah dan lembaga keagamaan telah menerbitkan kebijakan untuk memutus rantai persebaran covid-19, salah salah satunya dengan pembatasan sosial. Akibatnya laju perekonomian kian melemah, sektor pariwisata ditutup, pusat perbelanjaan semakin sepi pengunjung, sehingga pendapatan masyarakat kian menurun. Padahal ekonomi adalah salah satu faktor penting dalam keberlangsungan kehidupan.

Kajian yang dibuat oleh Kementrian Keuangan menunjukkan bahwa pandemi covid-19 memberikan implikasi negatif bagi perekonomian domestik seperti penurunan konsumsi dan daya beli masyarakat, penurunan kinerjan perusahaan, ancaman pada sektor perbankan dan keuangan, serta eksistensi UMKM. Pada aspek konsumsi dan daya beli masyarakat, pandemi ini menyebabkan banyak tenaga kerja berkurang atau bahkan kehilangan pendapatannya sehingga berpengaruh pada tingkat konsumsi dan daya beli masyarakat terutama mereka yang ada dalam kategori pekerja informal dan pekerja harian.

Sektor UMKM yang terguncang selama pandemi covid-19 selain daripada makanan dan minuman, juga yang terdampak adalah industri kreatif dan pertanian. Hasil survey menunjukkan bahwa kesulitan yang belum pernah dihadapi perusahaan sebelumnya akibat pandemi covid-19, yaitu dua dari tiga perusahaan yang menghentikan operasinya baik sementara maupun secara permanen, karena pendapatan menurun drastis.

Menurut Kemenkop UMKM ada sekitar 37.000 UMKM yang memberikan laporan bahwa mereka terdampak sangat serius dengan adanya pandemi ini ditandai 
dengan sekitar $56 \%$ terjadi penurunan penjualan, $22 \%$ permasalahan pada aspek pembiayaan, $15 \%$ masalah distribusi barang, dan $4 \%$ kesulitan mendapatkan bahan baku mentah. Penelitian ini bertujuan untuk mengetahui seberapa pengaruh masa pendemi covid 19 terhadap wirausaha kecil di indonesia.

\section{METODE PENELITIAN}

Metode penelitian ini adalah deskriptif kualitatif. Peneliti mengumpulkan dan mendeskripsikan semua efek yang terjadi akibat covid-19 dan dampaknya terhadap bisnis UMKM yang ada di Indonesia. Tetapi hanya ada sedikit riset empiris yang mengkaji terkait covid-19 dan dampaknya terhadap bisnis UMKM. Teknik pengumpulan data menggunakanteknik dokumetasi yakni dengan mengumpulkan data dari berbagainsumber referensi. Selain itu, penulis menggunakan literature review dan research article dari jurnal dan pemberitaan online untuk membuat kesimpulan dan evaluasi pada permasalahan yang dikaji. Metode analisis data berupa data sekunder baik berupa data kualitatif maupun kuantitatif dari jurnal dan pemberitaan online. Data sekunder mengacu pada informasi yang dikumpulkan dari sumber yang telah ada, diperoleh dari hasil riset, referensi dan pemberitaan online.

\section{HASIL DAN PEMBAHASAN}

\section{Adaptasi UMKM Dimasa Pademi Covid-19}

Keadaan di masa pandemi ini memaksa masyarakat untuk tetap stay at home dengan mengurangi aktivitas di luar rumah, hal ini menimbulkan efek harga barang kian melambung naik. Hal ini dirasaka oleh pedagang grosir yang biasanya menyuplai barang dengan jumlah banyak, kini harus mengurangi jumlah suplainya. Langkah ini dilakukan sebab pedagang khawatir barang tidak dapat terjual. Sementara bagi pedagang eceran, dampak omset dari pandemi ini tidak dirasa signifikan. Sebab, pedangang eceran hanya menuplai barag dengan jumlah sedikit sesuai dengan modal, sehingga resiko barang tidak terjual tidak terlalu banyak. Dari hal ini dapat dicerminkan bahwa Strategi yang digunakan pelaku UMKM dalam kegiatan ekonomi ialah dengan strategi mensuplai barang lebih sedikit dari sebelumnya, serta mengambil keuntungan sedikit dari tiap item barang yang dijual. Dengan strategi tersebut pemilik usaha sudah dapat beradaptasi. Omset para pelaku UMKM antara pedagang grosir dan pedagang eceran memiliki perbedaan. Terutamabagi pedagang grosir mengalami perubahan omset, yang sebelumnya $100 \%$ kini mengalami penurunan omset hingga $50 \%$. Sedangkan untuk pedagang eceran tidak mengalami penurunan signifikan. Temuan penelitian ini meunujukkan bahwa para pelaku UMKM baik pedagang eceran maupun pedagang grosir melakukan alternatif kegiatan jual beli melalui mengambil laba sedikit dari setiap item barang yang dijual, serta menyuplai barang dengan jumlah lebih sedikit dari sebelumnya guna menghindari resiko kerugian.

Pertumbuhan teknologi informasi yang kian pesat dapat dimanfaatkan oleh pelaku UMKM, penggunaan teknologi dapat menjunjang kegiatan UMKM dalam penjualan barang dagangannya maupun dalam pemasaran hal ini sejalan denhan pembatasan sosial serta kebijakan untuk stay at home yang diterbitkan oleh pemerintah. Dengan melakukan penjualan secara online pembeli dapat dengan mudah menemukan barang yang dicari, ketika pembeli melakukan cek out pada barang yang dipilihnya maka secara otomatis. Ketika barang sudah laris terjual, pemilik usaha dapat mensuplai barang dengan jumlah yang banyak. Namun banyak pelaku UMKM yang jalan ditempat karena minimnya inovasi.

Pelaku UMKM diharapkan mampu untuk berpikir kritis sekaligus inovasi 
dalam memproduksi barang dan jasa. Meski barang yang ditawarkan sejenis, tetapi jika masing-masing memiliki perbedaan yang signifikan maka membuat konsumen mempunyai banyak pilihan. Salah satu faktor penyebab pendistribusian barang terhambat sebab belum melakukan tekhnologi yang ada yaitu secara online. Padahal saat ini telah beberapa pelaku UMKM sudah melakukan pemasaran online yakni melalui media sosial, situs marketing, dan lain-lain.

UMKM yang mampu bertahan ditengah pandemi covid-19 ini antara lain adalah UMKM yang udah terhubung dengan ekosistem digital dengan memanfaatkan marketplace yang ada di Indonesia dengan mengadaptasikan bisnisnya dengan produkproduk inovasi, misalnya yang tadinya menjual produk-produk tas dan baju kemudian merubah produknya menjadi jual masker kain. Demikian halnya dengan industry ritel yang mampu bertahan, hal ini dikarenakan sebagian memanfaatkan penjualan melalui marketing digital.

Faktor yang mempengaruhi Pendapatan UMKM di Masa Pandemi Covid-19

Ada beberapa faktor yang mempengaruhi pendapatan UMKM di masa pandemi yaitu:

1. Social distancing, yakni serangkaian tindakan pengendalian infeksi untuk menghentikan atau memperlambat penyebaran penyakit menular seperti Covid-19. (Telkom Indonesia, 2020)

2. PSBB, didefinisikan sebagai Pembatasan kegiatan tertentu penduduk dalam suatu wilayah yang diduga terinfeksi penyakit untuk mencegah kemungkinan penyebaran penyakit atau kontaminasi. (UU 6/2018, Pasal 1 angka 11 tentang Pembatasan Sosial Berskala Besar)

3. Harga bahan baku meningkat. Bahan baku adalah persediaan yang dibeli oleh perusahaan untuk diproses menjadi barang setengah jadi dan akhirnya barang jadi atau produk akhir dari perusahaan. (Yusniaji dan Widajanti, 2013)

4. Kesulitan penjualan. Penjualan adalah suatu kegiatan yang terdiri dari transaksi penjualan barang atau jasa, secara kredit maupun secara tunai. (Fitriani dalam (Mulyadi, 2008))

5. Teknologi, yakni keseluruhan sarana untuk menyediakan barang-barang diperlukan bagi kelangsungan dan kenyamanan hidup manusia.

6. Bantuan dana, salah satu bentuk bantuan yang diberikan pemerintah adalah bantuan dana bergulir. Dana bergulir mulai diterapkan oleh Kementrian Koperasi dan UKM pada tahun 2000. (Asmara, 2018)

7. Influencer, yakni seseorang yang dapat mempengaruhi orang lain. Seorang dikatakan sebagai influencer jika orang tersebut memiliki pengikut yang banyak dan perkataannya dapat mempengaruhi orang lain. (Sugiharto dan Ramadhana, 2018)

8. Perbankan, Bank adalah badan usaha yang wujudnya memuaskan keperluan orang lain, dengan memberikan kredit berupa uang yang diterima dari orang lain dengan mengeluarkan uang baru kertas atau logam. (Astarina dan Hapsila, 2019)

9. Konsumsi, yakni kegiatan manusia menggunakan atau memakai barang atau jasa untuk memenuhi kebutuhan. (Wahyuni, 2013)

10. Kebijakan structural, kebijakan ini ialah suatu proses pembangunan ekonomi dan telah menghasilkan suatu pertumbuhan ekonomi yang tinggi. Perubahan struktur ekonomi terjadi akibat perubahan sejumlah faktor, biasanya hanya dari sisi permintaan agregat, 
sisi penawaran agregat atau dari kedua sisi pada waktu yang bersamaan. (Ayuningtyas (2016) dalam (Khaeruddin et al., 2020))

\section{Dampak Covid-19 Terhadap Umkm Di Indonesia}

Menghadapi tantangan ekonomi akibat pandemi covid-19 diperlukan berbagai jenis pendekatan baik secara makro maupun mikro. Secara pendekatan makro melalui kebijakan pemerintah guna membantu UMKM dan memulihkan perekonomian, pemerintah harus mempertimbangkan beberapa tindakan, diantaranya dengan mengumpumkan pasal sunset dari langkah-langkah dukugan ekonomi dan bisnis serta secara progresif mengadopsi dukungan yang terfokus pada pemulihan. Dalam hal ini pengaturan waktu serta kecepatan sangatlah penting. Namun penarikan dukungan yang terlalu cepatdapat berdampak pada kegagalan perusahaan yang membuat persaingan kian melemah, tetapi disisi lain dukungan yang berkepanjangan dapat berakibat distorsi, megurangi insentif guna berinovasi dan beradaptasi, serta memerngkap sumber daya dalam kegiatan yang tidak produkif.

Dukungan pemulihan inklusif dapat dilakukan pemerintah dengan memastikan jika arus perusahaan yang masuk maupun keluar dilakukan secara beertahap. Dalam hal ini terdapat peluang peningkatan status pailit, memberikan akses penutupan bisnis tidak produktif serta restrukturisasi bisnis yang layak, maupun meningkatkan kemapuan pengusaha untuk memulai bisnis baru setelah kegagalan. Sebab kebangkrutan dapat meningkat secara drastis, reformasi kebijakan harus mampu membatasi efek negatif dan penggunaan biaya pribadi bagi pegusaha gagal yang jujur. Semua ini membutuhkan pengembangan kriteria untuk menilai UMKM mana yang harus mendapatkan dukungan selama pemulihan dan transisi ke model bisnis baru. Semisal, memanfaatkan perkembangan Fintech dan alat-alat digital untuk penilaian risiko kredit yang lebih efektif, pemberian layanan dan pemantauanmenyeluruh dapat membantu mengatasi keterbatasan pendekatan tradisional untuk pembiayaan bisnis pada saat ketidakpastian seperti saat ini belum pernah terjadi sebelumnya. Sejauh ini, pemerintah belum memanfaatkan instrumen ini secara efektif.

Selain itu, instrumen pembiayaan non-utang harus digunakan lebih banyak untuk mengatasi lebih beragam kebutuhan dalam populasi UMKM dan memperkuat struktur modal mereka. Ketiga, dukungan pemerintah harus menjangkau para pengusaha dan UMKM yang dapat meningkatkan ketahanan ekonomi dan masyarakat di era pascaCOVID. Awal yang inovatif, kewirausahaan dan model bisnis baru harus dipromosikan. Pada saat yang sama, UMKM tradisional yang sebagian besar menghilang dan perusahaan mikro yang berjuang untuk mengambil manfaat dari transisi digital harus mempercepat digitalisasi dan adopsi teknologi, perubahan organisasi dan peningkatan keterampilan. Agar mampu keluar dari zona krisis, UMKM harus ditunjang dengan digitalisasi serta kemampuan tenaga kerjanya sebab, hanya sedikit inisiatif kebijakan yang bertujuan meningkatkan ketahanan jangka panjang dari potensi pertumbuhan umkm maupun bisnis yang sudah mapan.

Pandemi covid-19 berdampak pada ketidakstabilan dalam perekonomian terutama pada UMKM. Pelaku UMKM ini merasakan dampak langsung berupa penurunan omset. Untuk itu pelaku UMKM harus memiliki strategi untuk dapat bertahan di tengah pandemiini dan dituntut untuk dapat menyesuaikan diri terhadap kondisi yang terjadi. Menurut laura Hardilawati (2020) ada beberapa strategi yang dapat dilakukan UMKM untuk dapat mempertahankan bisnisnya, yaitu melakukan penjualan melalui e-commerce karena masyarakat sekarang banyak beralih ke belanja online. Melakukan pemasaran produk dengan memanfaatkan teknologi digital (digital marketing) untuk dapat menjangkau lebih banyak konsumen. Melakukan perbaikan kualitas produk dan kualitas serta jenis layanan. Melakukan pemasaran hubungan pelanggan untuk 
menciptakan kepercayaan konsumen dan menumbuhkan loyalitas pelanggan

\section{KESIMPULAN}

Berdasarkan hasil penelitian dapat disimpulkan bahwa hanya nsedikit inisiatif kebijakan yang bertujuan untuk meningkatkan ketahanan jangka panjang dari bisnis yang telah mapan dan potensi pertumbuhan UMKM. Penerapan strategi menyuplai barang yang lebih sedikit dari sebelumnya, serta mengambil laba sedikit dari item barang yang dijual, pemilik usaha sudah bisa beradaptasi. Selain itu, UMKM harus muncul dengan perlengkapan yang lebih baik secara digital dan dengan kemampuan tenaga kerja yang diperkuat.

\section{DAFTAR PUSTAKA}

Asmara,C. F. (2018). Implementasi Bantuan Dana Bergulir Bagi Pelaku Usaha. Fakultas Ilmu Sosial dan Ilmu Politik, Universitas Maritim Raja Al Haji

Astarina, I., Hapsila, A., \& Fitrio, T. (2019). The influence of discipline on lecturers' motivation and performance in Indragiri College of Economics (STIE) Rengat. International Journal of Scientific Research and Management, 7(09).

Khaeruddin, G. N., Nawawi, K., \& Devi, A. (2020). Faktor-Faktor Yang Mempengaruhi Pendapatan Umkm Di Masa Pandemi Covid-19 (Studi Kasus Pedagang Kaki Lima Di Desa Bantar Jaya Bogor). Jurnal Akrab Juara, 5(4), 86101.

laura Hardilawati, W. (2020). Strategi Bertahan UMKM di Tengah Pandemi Covid19. Jurnal akuntansi dan ekonomika, 10(1), 89-98.

Mulyadi. (2008). Perhitungan Harga Pokok Produksi, Makalah STIE Pandu Madania. Bogor.

Sugiharto, S. A., Ramadhana, M. R., \& Psi, S. (2018). Pengaruh kredibilitas influencer terhadap sikap pada merek (studi pada mahasiswa Fakultas Komunikasi dan Bisnis Universitas Telkom). Jurnal Ilmu Politik dan Komunikasi, $8(2), 1-7$

Wahyuni, S. (2013). Teori Konsumsi Dan Produksi Dalam Perspektif Ekonomi Islam. AKUNTABEL, 10(1).

Yusniaji, F., \& Widajanti, E. (2013). Analisis Penentuan Persediaan Bahan Baku Kedelai yang Optimal dengan Menggunakan Metode Stockhastic pada PT. Lombok Gandaria. Jurnal Ekonomi dan Kewirausahaan Vol, 13(2), 158-170. 